\title{
The 'Union for the Mediterranean', the European Neighbourhood Policy and the Barcelona Process: Old wine in new bottles?
}

\author{
Dr. Michael Reiterer
}

The ancient Romans called the Mediterranean "mare nostrum “, 'our' e.g. 'their' sea a perspective well understood when viewing the world from Rome. This is also testimony that already more than 2000 years ago, Northern Africa was of considerable importance in economic, political but also cultural terms. It is hence not surprising that the Romans fought the Punic wars and decided - just to be on the safe side - not only to defeat but to annihilate the regional Phoenician competitor Carthago ("Carthago delenda est") in order to extended their reign into this area.

Luckily, times are changing. The European Union (EU) acts as a soft power that is not out to destroy its competitors. While nobody wishes back the colonial attention of former times, Mediterranean countries are today confronted with the problem of a lack of competition and attention for their area. Of course, Western governments and media deal with the ongoing Middle East problem, including the Israeli-Arab conflict. They also show a great interest in exploiting the region's oil reserves and want to cooperate with the Mediterranean countries to curb illegal migration. But for the Mediterranean countries this is simply not enough. They want to move beyond the times when cooperation was all about exploitation and occasional lectures in democracy and human rights.

The EU regards the Mediterranean countries as 'neighbours', a status they share under the European Neighbourhood Policy (ENP) with countries bordering the eastern frontiers of the Union. 
The "raison d'etre" of the ENP lies in the fact that the neighbours of the EU not only have relations with the individual Member States but also the European Union as a whole. As the common foreign policy of the Union is progressively, albeit slowly, developing, the relationships between the Union and its neighbours need to be regularly updated and adapted. In substance, the ENP strives to avoid the emergence of new dividing lines between the enlarged Union and its new neighbours in strengthening prosperity, stability and thereby the security of all concerned. For Benita Ferrero-Waldner, Commissioner for External Relations and European Neighbourhood Policy, and the driving force behind the development of the ENP to a key foreign policy tool of the EU, the ENP should avoid borders becoming new barriers. As Ferrero-Waldner puts it, this can be done by offering "our eastern and southern neighbours many of the benefits previously associated only with membership, such as a stake in our internal market, involvement in EU programmes, and cooperation in transport and energy networks". Hence, the ENP aims at giving non- EU member states "a privileged form of partnership $\left({ }_{4}\right)$, irrespective of the exact nature of the future relationship with the EU."

While Dieter Mahncke traces the origins of the ENP back to 1989 when the European Economic Area was discussed, he dates the actual birth of the ENP back only to 2002, "when the UK pushed for a 'wider Europe' initiative aimed at Ukraine, Belarus, Moldova and Russia”. Later in that year also the Mediterranean countries were included in the "Wider Europe' initiative at the Copenhagen Summit which eventually lead to the change in name from the 'wider Europe' initiative to 'European neighbourhood policy', since the Mediterranean partners are not part of Europe. The European Commission concretised the project in its Communication "Wider Europe-Neighbourhood: A New Framework for Relations with our Eastern and Southern Neighbours". This Communication laid the basis for the 2004 "Neighbourhood Policy-Strategy Paper", and the 2006 "Communication on Strengthening the European Neighbourhood Policy". 
The 'Union for the Mediterranean', the European Neighbourhood

Policy and the Barcelona Process : Old wine in new bottles?

(Reiterer)

In the context of the Mediterranean, the ENP individualises and enhances, through action plans based on country reports, the existing cooperation within the framework of the Barcelona Process, which is a "multilateral and regional approach". The more individualistic approach also provides the opportunity for larger "active cooperation in the field of freedom, security and justice, promoting the rule of law". The ENP thus not only focuses "exclusively on economic issues" but also tackles "uncomfortable governance or human rights issues."

In the course of the development of the ENP, the 2003 European Security Strategy established the geo-strategic importance of the Mediterranean for the EU:

"The integration of acceding states increases our security but also brings the EU closer to troubled areas. Our task is to promote a ring of well governed countries to the East of the European Union and on the borders of the Mediterranean with whom we can enjoy close and cooperative relations...

Resolution of the Arab/Israeli conflict is a strategic priority for Europe. Without this, there will be little chance of dealing with other problems in the Middle East. The European Union must remain engaged and ready to commit resources to the problem until it is solved. The two state solution - which Europe has long supported - is now widely accepted. Implementing it will require a united and cooperative effort by the European Union, the United States, the United Nations and Russia, and the countries of the region, but above all by the Israelis and the Palestinians themselves.

The Mediterranean area generally continues to undergo serious problems of economic stagnation, social unrest and unresolved conflicts. The European Union's interests require a continued engagement with Mediterranean partners, through more effective economic, security and cultural cooperation in the framework of the Barcelona Process. A broader engagement with the Arab World should also be considered." 
The important wealth gap between the Northern and Southern shores of the Mediterranean, the relationship is put at $1: 10$, is a serious threat to the security and stability of the region. The unremitting migratory flows towards Europe are the visible expression of this unbalanced, asymmetrical and ultimately unhealthy situation. Above all, consequences of climate change (desertification) tend to reinforce the disparities between rich and poor, developed and undeveloped. According to the joint paper of the High Representative and the European Commission on 'Climate change and international security' (March 2008), North Africa and the Middle East are going to be particularly affected by climate change. If the still mounting demographic pressure is added, the cocktail's explosive nature becomes the more apparent.

Tackling the wealth gap is hence essential to stabilise the region and to assure peaceful development. Investment to create employment and to improve infrastructure is essential, a fact recognised by the ENP in stressing the importance of promoting prosperity.

Moreover, Mediterranean oil and gas producing countries, such as Algeria, Libya and Syria, are part of the European energy supply network and play potentially an increasingly important role in assuring and diversifying energy supply. The need to bind the Mediterranean countries to the EU also for reasons of energy security has been explicitly recognised in the above mentioned 2004 Neighbourhood Policy Strategy Paper. It therefore calls for an enhancement of "our (EU) strategic energy partnership with neighbouring countries", which constitutes "a major element of the European Neighbourhood Policy".

The last round of EU enlargement $(2004,2007)$ confirmed the eastern and south-eastern orientation of the Union after the fall of the iron curtain (1989) - Malta and Cyprus being the exceptions. The rotating presidencies of the EU Council serve as a mechanism built into the EU system to balance or counterbalance various national and geopolitical interests thereby forging EU policies. Various presidencies were important in the 
The 'Union for the Mediterranean', the European Neighbourhood

Policy and the Barcelona Process: Old wine in new bottles?

(Reiterer)

development of the Barcelona Process : the Portuguese presidency laid the ground at the 1992 Lisbon Summit, while the Spanish presidency called for the meeting of foreign ministers in 1995 to formally launch the process. Other holders of the presidency had different priorities, reflecting their particular geopolitical and economic interests. Countries like Germany, Austria and the UK traditionally pushed for the Eastern enlargement of the Union. Finland, on the other hand, used its presidency in 2006 to shift the focus to the Northern Dimension of the EU, which also includes non-EU members Russia, Norway and Iceland.

It is ironical, yet underlining the importance of the Eastern dimension of Europe that the French EU Presidency which had organized the Mediterranean Summit in July 2008, leading to the establishment of the “The Barcelona Process: Union for the Mediterranean" (BPUfM), had to change gear quickly in concentrating its efforts on condoning the crisis between Georgia and Russia in calling a special meeting of the European Council in September 2008.

The pendulum swung back quickly: As a sort of counterweight to the Mediterranean Union, the Czech presidency of the first half of 2009 announced that "in accordance with historical ties and current challenges, the Presidency will give priority to the strengthening of cooperation between the EU and the Eastern European and Southern Caucasus countries." Therefore it "will strongly strive to push forward for the introduction of the Eastern Partnership with the aim of achieving balance between the individual geographical partnerships of the EU."

The BPUfM's membership includes the 27 States of the EU, the North African States of Mauritania, Morocco, Algeria, Tunisia and Egypt. Libya was represented at the meeting by its Foreign Minister; but will not join as a member. Furthermore, the Middle East States Israel, Jordan, Lebanon, Syria and the Palestinian Authority, three states of former Yugoslavia - Croatia, Bosnia-Herzegovina, Montenegro but not Serbiaand the Principality of Monaco joined as costal states. At their meeting in 
Marseille (November 2008) foreign ministers acknowledged the "dedication and interest expressed by three new members $\cdots$ Bosnia and Herzegovina, Republic of Croatia, together with Albania, to add their efforts in contributing to a successful integration of the Adriatic countries in the existing and future initiatives and projects of the Euro-Mediterranean region."

The rather clumsy name and orthography "The Barcelona Process: Union for the Mediterranean” - instead of 'Mediterranean Union' which was meant for a union separate from the European Union - indicated a shift in emphasis but also a typical European compromise. At the end, reason should prevail and the Foreign Ministers decided at their meeting in Marseille in November 2008 that as from Marseille the BPUfM should be called "Union for the Mediterranean (UM)".

The original reference to Barcelona was a reminder that this Union was not created out of the blue but is based on the Euro-Mediterranean Partnership (Euromed or EMP) launched in 1995 in Barcelona. In recognition of this fact, Foreign Ministers accepted 2008 the candidature of Barcelona for the Secretariat.

Already in 2005 the basic goals, ideas and working methods were outlined in the 'Barcelona Declaration', serving as the basis for what became known as the 'Barcelona Process'. Although designed as a comprehensive multilateral process with political, security, social, cultural and human aspects, the economic project - the establishment of a free trade area (FTA) by 2010 - remained the flag ship project. Overall, however, the Barcelona Process lacked effectiveness and visibility enhanced by the various regional conflicts as well as the economic and political asymmetry. The latter increased after $9 / 11$ because of the Islamic element and systemic inconsistencies. The 2009 crisis in the Gaza Strip was a grim reminder. 
The 'Union for the Mediterranean', the European Neighbourhood

Policy and the Barcelona Process : Old wine in new bottles?

(Reiterer)

\section{Economic relevance of the Mediterranean for the $\mathrm{EU}$ and vice versa in 2007 :}

Compared to its main political competitors, the Central and Eastern European countries, the Mediterranean constantly underperformed since 2001 in terms of GDP growth. Admittedly, the gap narrowed over time: in 2001 the growth figures were $4.3 \%$ and $2.2 \%$ and in $20066.6 \%$ and $4.5 \%$ respectively. But during the period from 2001 to 2006 the Mediterranean was well behind South Asia, East Asia and even SubSaharan Africa as far as growth figures are concerned.

EU exports to the MED countries were worth around $€ 120$ billion, or 9.7\% of total EU exports, in 2007. Imports from the MED countries represented around $7.5 \%$ of total EU imports, worth $€ 107$ billion, in 2007. EU exports to the MED countries have grown at an annual average of $8 \%$ since the mid-1990s. This amounts to an increase in export value of about 250\% between 1995 and 2007. The largest average annual growth rates are recorded for the West Bank and Gaza, albeit from a low level, followed by Turkey, Morocco, Jordan and Algeria.

From the MED countries' perspective, the EU takes in around 47 percent of their exports. Since 1999 MED exports to the EU are increasing annually by an average of $10 \%$. EU imports have thus doubled over ten years, with imports increasing most from West Bank and Gaza (again from a low level), followed by Turkey and Algeria. Dominated by fuels (22\%) the EU imports from MED countries consist primarily of textiles and clothing (18.3\%) and machinery and transport equipment (17.5\%). Among the MED countries, Turkey's position is particular because of its customs union with the EU, its status as a EU candidate country and its demographic weight. Turkey bought $4.3 \%$ of EU exports (€53 billion) in 2007, while providing $3.3 \%$ of EU imports ( $€ 47$ billion) in 2007 . The annual average rate of EU export growth to Turkey between 1995 and 
2007 amounted to $12 \%$.

In order to facilitate trade relations the EU has concluded Association Agreements with all of its MED partners. These have all entered into force except the one with Syria. These agreements foresee a gradual liberalisation of trade in all industrial goods, and duty-free access for as much as $80 \%$ of agricultural exports. This has been instrumental in doubling MED exports to the EU since 1995 and halving the region's trade deficit with the $\mathrm{EU}$ to $10 \%$ of their total trade.

\section{Intraregional integration among the Mediterranean partners}

Although a few Southern Mediterranean states are making some progress in fostering regional economic integration, North Africa remains the least regionally integrated region in the world. The Agadir Agreement $(2004)$ created a free trade area between Morocco, Tunisia, Jordan and Egypt, but has shown mitigated results in increasing trade flows amongst the partners, which do not share a common border. Turkey, in addition to its FTA with the EU, is also a regional hub due to its bilateral FTAs with Tunisia, Morocco, Israel and Egypt. As differing rules of origin tend to hinder trade, the EU has agreed to create a pan-Euromed system of cumulation to ensure that a product produced in more than one country in the region, will continue to benefit from preferential access to the European Union or to other Mediterranean markets.

In addition to improving trade relations, the $\mathrm{EU}$ launched regional services and establishment negotiations in Marrakesh in 2007 with the Agadir group, which were followed by the launch of bilateral negotiations in 2008. Improving terms of services trade is designed to help attract much needed EU investment in the Mediterranean region, which is currently clearly below potential. 


\section{From the (French) Mediterranean Union to the (European) Barcelona Process: Union for the Mediterranean}

As the name suggests, it took quite some political maneuvering to anchor the Union for the Mediterranean in the general institutional framework of the EU and the European Neighbourhood Policy.

This result was not at all clear from the outset. Presidential candidate Sarkozy proposed in 2007 the Mediterranean Union as a French project with France in the driving seat. It should redirect European attention to the region, on which it "had turned the back", because of its concentration on the North and East of Europe. Not without pathos Sarkozy proclaimed that the "future of Europe is in the south. The European dream needs the Mediterranean dream." Part of the dream certainly was to invite the Mediterranean countries to follow the French-German example of reconciliation. Referring to the Barcelona process, Sarkozy remarked dryly that "it had not met its objectives" because of the EU's priority for the East especially in terms of trade. Hence, the attention needed to overcome the invisible border cutting the Mediterranean into two regions was missing.

On the French national level, Sarkozy wanted to give France, struggling with the demise of international influence in Africa and in competition with Germany's 'Ostpolitik', a leading role in its near abroad, the Mediterranean. Adding Paris to Rome and Barcelona to Mediterranean cities seemed attractive. The improvement of bilateral ties with the former colony Algeria was also on the agenda while Sarkozy surely hoped that his Mediterranean initiative would also make him more popular with the French electorate of North African origin or background (pieds noirs). In the first half of 2008 when France exercised the EU presidency it could push this agenda, but the presidency obliged France at the same time to moderate the national agenda because of the need to take into account European interest. 
While the national dimension was successful-Nicolas Sarkozy was comfortably elected President-problems emerged quickly on the European level:

When inviting Portugal, Spain, Italy Greece, and Cyprus to take the initiative with France, Sarkozy first, forgot to invite Malta and secondly, stated unambiguously that the Mediterranean Union will "work closely with the European Union" (e.g. it would be a separate institution) although it "one day could have common institutions" with the EU since the two regions' destinies are linked. It is in this context that Sarkozy said that "Europe cannot enlarge indefinitely", that Europe needs frontiers and limits to guard its identity, and that "Turkey has no place in the European Union because it is not a European country." Turkey, however, made it unmistakably clear that it was only interested in membership in the European Union with which it is negotiating membership. Any second class or alternative membership like in the BPfMU only was not acceptable. France had to acquiesce. Accession negotiations continued and Turkey agreed to participate in the re-launched BPMU project.

This re-launch became necessary as the other Members of the Union as well as the European Commission - the latter charged to look after the European interest - made it clear that there cannot be a second restrained Union whatsoever, independent from the European Union. This message was communicated unmistakably by the German Chancellor Angela Merkel to Mr. Sarkozy. In order to preserve the project, announced as the centerpiece of the French presidency, Sarkozy acquiesced again.

These two features, firstly, a separate new institution, and secondly, to offer Turkey an alternative membership to the EU in a Mediterranean organization, nearly grounded the project from the beginning. Most European partners and especially Germany categorically refused a new institution. Therefore, only after Sarkozy had amended the project it could continue. However, there was no more talk about a Mediterranean 
The 'Union for the Mediterranean', the European Neighbourhood

Policy and the Barcelona Process : Old wine in new bottles?

(Reiterer)

Council built on the example of the Council of Europe or a G8Mediterranean. The Mediterranean initiative definitely become an 'EU project'

Similarly, the list of issues and projects to be undertaken in the Mediterranean context had to be changed. The idea of a Mediterranean collective security system under French leadership vanished. Jointly managed immigration, though not in the first pillar, and concern for the environment including the cleaning up the Mediterranean remained on the agenda. The development of nuclear energy remains a French project under the heading of co-development, which originally contained many projects like the sharing of technology, pharmaceuticals, the establishment of common universities and laboratories, the negotiation of free trade agreements, the creation of a Mediterranean Investment Bank on the model of the European Investment Bank, the common management of water, and the setting up of a common energy policy. The fourth pillar would have been the creation of common sphere of law and security to fight corruption and terrorism.

Therefore the above mentioned change in name from 'Mediterranean Union' to 'Barcelona Process: The Mediterranean Union' was more than just a linguistic exercise but signaled that the project was part of the ongoing Barcelona Process and therefore part of the entire European Union, not only its coastal states.

The main value added of the new project was first, the highlighting of the political importance of the region exemplified in the introduction of a biannual summit; secondly, an effort to rebalance the Union towards the South after the Eastern enlargement; thirdly, to revive the Barcelona Process which had not delivered as much as had been hoped and fourthly, stressing the partnership element in introducing a shared presidency. All these efforts but in particular the last one, the double presidency stand for co-ownership of the new process.

The parallel drawn by Mr. Sarkozy with the French-German peace 
project at the cradle of the EU appears however to come close to dangerous rhetoric because firstly, it is raising too high expectations and, secondly, like many parallels is not a correct one. While France and Germany were involved in many wars in the $19^{\text {th }}$ and $20^{\text {th }}$ century, Europe as Europe was never at war with Maghreb or Mashrek countries to fight for preeminence in Europe. However, France and Italy acted as colonial masters in the region and released control only after wars. This legacy has repercussions until today, as some relationships remain difficult: France - Algeria, Spain-Morocco, Italy-Libya although lately improving. The situation in the Palestinian territories is very instable and of an explosive character. Tensions between Syria and Lebanon and within Lebanon only abated recently when the two countries established diplomatic relations for the first time. The political situation in Libya moved from Lockerbie to the renunciation of the nuclear programme, to peace with the US and to the freeing of the Bulgarian medical staff. But it stays highly volatile as evidenced by the non-participation of Libya in the Union for the Mediterranean.

The BPUfM and the European Neighbourhood Policy, the latter a policy devised for EU's southern and eastern neighbouring countries, are mutually reinforcing. While this does not pose a real problem for the Mediterranean countries - except Morocco which unsuccessfully applied for EU membership in 1987 - the term and concept "European neighbourhood' poses a problem for countries such as the Ukraine, Georgia or Moldova since they regard themselves as European. Thus the question is whether one refers to these countries as 'European neighbours' or 'neighbours of Europe'.

Semantics apart, the ENP is presently still devised for those countries without an accession perspective. Within that framework everything but institutions can be shared and future changes are not ruled out ("offer more than partnership and less than membership, without precluding the latter"), as then Commission President Romano Prodi put it in 2002. 
The 'Union for the Mediterranean', the European Neighbourhood (Reiterer)

Policy and the Barcelona Process: Old wine in new bottles?

The idea of the BPUfM had also inspired Sweden and Poland to propose a similar arrangement in the east, including the Ukraine and offering a perspective to Belarus. In the wake of the Georgian crisis the Swedish foreign minister Carl Bildt reverted to this idea and hence the Eastern Partnership (EaP) was set up in December 2008 covering cooperation with Armenia, Azerbaijan, Belarus, Georgia, Moldova and the Ukraine. According to the Communication on the Eastern Partnership "the EaP should bring a lasting political message of EU solidarity, alongside additional, tangible support for their democratic and market-oriented reforms and the consolidation of their statehood and territorial integrity" contributing "to the stability, security and prosperity of the EU, [its] partners and indeed the entire continent. It is clear that the Eastern Partnership will be pursued in parallel with the EU's strategic partnership with Russia."

Like the Northern Dimension, this project also binds Russia closer to the EU and complements the Four Common Spaces (economic; freedom, security and justice; external security; research and education) concluded 2003 between the EU and Russia after the Russian refusal to join the ENP. The renegotiation of the 1997 Partnership and Cooperation Agreement was temporarily put on hold by the European Council because of the conflict in Georgia but were restarted by the end of 2008 .

In addition, Poland favours closer cooperation with the Black Sea countries for security and immigration control reasons. This gave rise to another union project, the Black Sea Union which also includes Russia. Albania, Bulgaria, Greece, Romania, and Turkey as members of the Barcelona Process-Mediterranean Union could be the link to the Organisation of Black Sea Economic Cooperation (BSEC) founded in 1992 among Albania, Armenia, Azerbaijan, Bulgaria, Georgia, Greece, Moldova, Romania, Russia, Turkey and Ukraine. With Turkey serving as the geographical connection this could amount to a manifestation of interregionalism in the form of cooperation between regional organisations 
『日本 $\mathrm{EU}$ 学会年報』第 29 号, 平成 21 年 4 月

forming a 'regime' between the Mediterranean and the Black Sea. However, with the European Commission joining as an observer it will assume part of the bridging and steering function as evidenced in presenting a Communication on 'Black Sea Synergy:A new regional cooperation initiative' (2007) as well as a Communication on its implementation (2008).

\section{The project outline of the European Commission}

Once the political decision was taken at the European Council, March 13 $-14,2008$ to anchor the French project in the EU, it fell as usual on the European Commission to prepare the scheme Its communication 'Barcelona Process : Union for the Mediterranean' formed the base for the agreement at the Paris Summit on July 13, 2008. The Communication confirms the "centrality of the Mediterranean for Europe" but shares the French analysis that the Barcelona Process had shortcomings and therefore "needs to be revisited and given greater political prominence." Providing the only forum where all Mediterranean partners engage in a constructive dialogue, the Process represents a "strong commitment to regional stability and democracy through regional cooperation and integration". It is challenged to the limit by the persistence of the conflict in the Middle East which caused delays in achieving reform, good governance and participatory democracy. The Communication also recognizes the positive role of the Anna Lindh Foundation for the Dialogue between Cultures in promoting peaceful coexistence and establishing channels of communication among political and economic actors, the media and civil society. While the Euro-Mediterranean free-trade area project is expected to increase trade and investment by 2010, agriculture and services remained largely excluded and need more attention. This also applies to the promotion of South-South economic integration. The combined effect of these shortcomings as well as insufficient growth and continued demo- 
The 'Union for the Mediterranean', the European Neighbourhood

Policy and the Barcelona Process : Old wine in new bottles?

(Reiterer)

graphic expansion lead to a slower than expected process and the widening of the prosperity gap. Therefore an intensification of common efforts in quantitative and qualitative terms is required, including a change of domestic economic policies of the Mediterranean partners. This will only be possible if interest in the Mediterranean policy moves up the European political agenda. This will, however, only happen if the Process proves its utility and effectiveness in daily life which in turn would lead to higher visibility, lacking so far.

The perceived lack of co-ownership of the process, taking into account the imbalance in the institutional set-up of the two sides, also needs to be addressed. Instead of re-inventing the wheel, the multilateral partnership should be built on the 'Barcelona acquis' and should make use of the four chapters of cooperation reminiscent of the OSCE process:political dialogue; economic cooperation and free trade; human, social and cultural dialogue; migration, social integration, justice and security. The traditional structure of interregional dialogues e.g. senior officials' meetings, experts meetings, and meetings of the political level (foreign ministers to oversee progress) will be maintained but complemented by a biannual summit, the introduction of a co-presidency and a secretariat. On the European side the co-presidency has to be in line with the relevant provisions of the EU treaty - under the present regime the representative of the rotating presidencies and the Commission. A new set-up under the Lisbon Treaty would install a High Representative for Foreign and Security Policy who would chair the Foreign Affairs Council during the five years' function period but whether and when the Lisbon Treaty will be implemented is not known yet. On the Mediterranean side, a co-presidency shall last for two years and shall be decided by consensus. In recognition of the institutional advantage of the EU machinery, a new secretariat in Barcelona shall improve institutional governance to enhance co-ownership and a more balanced partnership. Furthermore, a Brussels based committee, the Joint Permanent Committee, shall not only prepare meetings, 
follow up on initiatives and projects, but "may act as well as a mechanism to react rapidly if a crisis situation arises in the region that requires the consultation of Euro-Mediterranean partners".

Regional integration and cohesion shall be increased through regional and trans-national projects among the members, to be decided at the summits by consensus. In implicit reference to the Middle East problem and in attempting to pre-empt a situation which would endanger the whole process, hosts of meetings are reminded always to invite all partners.

In focusing on common projects to promote regional cohesion, economic integration, and infrastructural interconnections, the process should gain visibility and demonstrate its utility and relevance, also for the individual citizens of the region. Specific selection criteria are recommended:regional, sub-regional and trans-national projects allowing also for cooperation of a restrained number of countries; manageable size of projects and relevance; promotion of balanced and sustainable development, regional integration, cohesion and interconnectedness; respect for financial feasibility to insure involvement of private sector participation and financing; mature projects to be launched quickly. In an annex to the Communication, the Commission proposes four projects:a highway of the sea; the depollution of the Mediterranean and sound environmental governance; civil protection; a Mediterranean solar energy plan. The latter is part of the EU's efforts to develop Euro-Mediterranean infrastructures, such as the Euro-Mediterranean gas and electricity ring and to facilitate energy trade in general as part of its policy to raise energy security to the political level in establishing a coordinated EU energy security diplomacy.

Having the democratization discussion within the EU in mind, the Commission recommends the upgrading of the Euro-Mediterranean Parliamentary Assembly as the "legitimate parliamentary representation".

The principle of complementarity in relation to existing frameworks (ENP, ACP) and the 2007 EU-Africa Strategy is underlined. 
The 'Union for the Mediterranean', the European Neighbourhood

Policy and the Barcelona Process : Old wine in new bottles?

(Reiterer)

Already under the existing scheme, the EU had contributed from 20002007 under various programmes 6.9 billion euro (Annex II). Some additional sources of funding are indicated such as private sector participation, bilateral funds of Member States, contributions of the Mediterranean partners, international financial institutions and the Euro-Mediterranean Investment and Partnership Facility as well as the Neighbourhood Investment Facility.

\section{The project as adopted by the July 2008 Paris Summit}

The Joint Declaration of the Paris Summit for the Mediterranean (Paris, 13 July 2008) follows closely the principles set out in the Communication of the European Commission outlined above. 'A strategic ambition for the Mediterranean' is developed at the outset with the goal of creating an "area of peace and stability $\cdots$ including the long term possibility of establishing a Euro-Mediterranean pact to that end." In reference to the Barcelona Declaration (1995), the promotion "of regional security by acting in favour of nuclear, chemical and biological non-proliferation through adherence to and compliance with a combination of international and regional non-proliferation regimes and arms control and disarmament agreements such as NPT, CWC, BWC, CTBT and/or regional arrangements such as nuclear weapons-free zones, including their verification regimes, as well as by fulfilling in good faith their commitments under arms control, disarmament and non-proliferation conventions" is reiterated. The Middle East shall be free of "weapons of mass destruction, nuclear, chemical and biological, and their delivery systems." Armament shall not be "beyond '. legitimate defence requirements" based on confidence and security-building measures. A comprehensive solution for the IsraeliPalestinian Peace Process is supported, as well as the indirect peace talks between Syria and Israel under the auspices of Turkey.

Respect for democratic principles, human rights and fundamental free- 
doms are identified as the base for building a common future. Given the nature of the political regimes in the Mediterranean-Israel is widely regarded as the only democracy - the implementation of these and other 'shared values' could lead to regime change and consequently the down fall of the governing elites or families. This call, however, will not be answered quickly.

The eradication of terrorism "in all its forms and manifestations without qualification, committed by whomever, wherever and for whatever purpose" through inter alia the full implementation of the 2005 EuroMediterranean Code of Conduct on Countering Terrorism is defined as a common goal. Taking into account that Islam is the predominant religion of the Mediterranean partners, "the complete rejection of attempts to associate any religion or culture with terrorism" is reiterated as well as the need to eradicate the underlying causes such as continued conflict, occupation, oppression, poverty, lack of human rights and good governance, and disrespect for religions and cultures.

In defining the 'scope and main objectives' of the Process, the Heads of State and Government confirm the Barcelona acquis in the form of its four chapters; the importance of economic cooperation; the Euromed Trade Road Map 2010 which also provides for a "smooth, efficient and business-friendly trade facilitation mechanism".

Furthermore, the importance of managing migration not only by preventing illegal immigration but also by providing a framework for legal migration in an integrated approach is highlighted.

In establishing the complementarity of the Process in its regional dimension, it is stated that the Process "will be independent from the EU enlargement policy, accession negotiations and the pre-accession process". It is thereby clarified that the Mediterranean partners cannot deduct from the Process an accession perspective. In order to assure complementarity, duplications with ongoing projects of the Barcelona Process have to be avoided. 
The 'Union for the Mediterranean', the European Neighbourhood Policy and the Barcelona Process : Old wine in new bottles?

(Reiterer)

Increased co-ownership is provided for by the co-presidency, the institutional governance, the establishment of a Joint Secretariat of a technical nature and the Brussels based Joint Permanent Committee.

The Summit also endorsed the project driven nature including the principle of variable geometry projects as well as the mentioned multiple sources for funding. In this context it is clarified that the funding for the projects "will not be financed at the expense of the existing bilateral allocations" under the ENP, the European Development Fund or the Preaccession Instrument. In an annex to the Joint Declaration, the goals to be realized through common projects are outlined and set in the context of the goals of the Barcelona Declaration. The Heads of State or Government added to the four projects proposed in the Commission's Communication 'Higher Education and Research' and a 'Euro-Mediterranean University' with its seat in Slovenia as well as a 'Mediterranean Business Development Initiative'.

\section{Results of the first Ministerial Meeting, Marseille, November 3-4, 2008}

In addition to the already above mentioned change of name and agreement on the location of the secretariat in Barcelona, to be headed by a representative of a Southern Mediterranean country assisted by five deputies including one from Israel and the Palestinian Authority, the question of Arab League participation was lifted. Differences between the Arab group and Israel could be adjusted. Consequently, the League may participate in all meetings at all levels.

Efforts of the Quartet as well as of the Arab Peace Initiative were generally commended. The two parties to the conflict were invited "to respect their commitment to immediately implement their respective obligations under the performance-based Roadmap to a permanent two state solution to the Israeli-Palestinian conflict, and call on the parties to 
refrain from any measure that might prejudice the outcome of the negotiations".

In recognition of the need to work towards a better understanding of the peoples participating in the new Union, Ministers also reiterated "their commitment to do their utmost effort with a view to resolving conflict, ending occupation, confronting oppression, reducing poverty, promoting human rights and good governance, improving intercultural understanding and ensuring respect for all religions and beliefs."

Concerning the institutions, the co-presidency was confirmed but the European side was not able to combine the rotating presidencies of the Council with the French wish to assume together with Egypt a two years' term. Furthermore, there was agreement on strengthening the parliamentary dimension of the Union through the Euro-Mediterranean Parliamentary Assembly.

In line with the endeavor to achieve results through the successful completion of concrete projects, the work programme for 2009 was accepted and concretized by ministers in the following areas: Political and security dialogue; maritime safety; economic and financial partnership (energy, transport, agriculture, urban development, water, environment, information society, tourism, establishment of a Euro-Mediterranean Free Trade Area, economic dialogue, industrial cooperation, statistics cooperation); social, human and cultural cooperation (genuine social dimension, health, human development, Euro-Mediterranean Higher Education and Research Area, dialogue among cultures, cultural diversity; justice and law; role of women in society; Euromed Youth; civil society and civil actors; visibility of partnership; migration).

Furthermore some progress is reported on the projects enumerated in the Paris Declaration, namely on the de-pollution of the Mediterranean; maritime and land highways; civil protection; alternative energies: Mediterranean solar plan; higher education and research:EuroMediterranean University; the Mediterranean Business Development 
Initiative.

\section{Conclusions}

The formation of the BPUfM and the process which lead to its integration as the Union for the Mediterranean into the institutional framework of the EU is a telling case of 'Europeanisation' of a national project and represents a triumph for institutionalism.

From a constructivist point of view the rational French national interest met the combined interests of other Member States and institutions of the EU (European Council, European Commission) leading to the construction of a European interest (Europeanisation) - a process in which the Member States acquiesced to accept the modified project over time to preserve it and maintain a fragile unity.

However, the latter came to light when President Sarkozy used the French co-presidency to initiate a diplomatic mission during the Israeli intervention in Gaza in parallel to the official EU action under the Czech presidency. The instrumentalisation of the Mediterranean Union to project French influence beyond the six months presidency of the Council of the European Union is an aspect of functionalism. Nevertheless, in integrating the French proposal into the institutional framework of the EU, the project has become "an aspect of European foreign policy, a reality that is in some tension with the principle of equality implied by the term "partnership".

2000 years ago mare nostrum meant the home turf (sea) for the Roman Empire. Nowadays the prevailing European power is neither Italy, nor Spain, nor Greece, nor France alone or the littoral Member States of the EU but the European Union in toto, a lesson to be learnt by France. As in the past, proximity establishes and attributes importance.

In terms of International Relations theory, the development of the BPUfM is an example of neofunctionalism in reverse: a negative spillback 
in the integration process was avoided as other Member States and the European Commission insisted on a common approach to the Mediterranean since their strategic ambition could only be realized through institutionalized cooperation based on the existing Barcelona Process albeit in a reinvigorated form. A parallel could be drawn to de Gaulle's empty chair policy of 1965 : whereas he boycotted the EC institutions, his successor wanted to bypass them. The price paid by other Members this time was not the Luxembourg Compromise (veto power in case of vital national security interests being at stake) but the Europeanisation of the project. The need to find progress and development in the Mediterranean, a relatively compact geographical area, creates the need for cooperation in an interdependent sub-system.

Hence the role played by the EU institutions was crucial. First, the European Council directed the new project firmly within the existing Barcelona acquis. Secondly, the European Commission developed the project through its Communications within known parameters. These features highlight the independence of EU institutions from the Member States. The institutions fostered the integration process according to their preferences (European interest) in making use of their autonomy from Member States (agency). In preventing the set up of a new international organisation, the EU institutions certainly contributed to keeping the transaction costs of European integration low.

Incidentally keeping the project within the institutional framework of the EU was also in the interest of the European institutions themselves (institutional self interest) to maintain their influence as they would not have played a role in the initial French project. This is an expression of the principal-agent relationship between the Member States and the institutions of the EU. The shaping influence and importance of existing agreed rules (the (Barcelona) acquis) was clearly demonstrated.

The never ending discussion of widening vs. deepening of the Union also plays a role. BPUfM can be perceived as a further deepening of an 
The 'Union for the Mediterranean', the European Neighbourhood

Policy and the Barcelona Process : Old wine in new bottles?

(Reiterer)

existing relationship. Drawing on EU experience, the multiple speed approach in project implementation is foreseen to facilitate the (cumbersome) intergovernmental consensus based decision making process among partners.

The institutions of the BPUfM, once effective, could contribute to more coherence in the process and help to smoothen the contradictions of the multilayered structure of the process (EUROMED, ENP, BPUfM) because of the (still existing) pillar structure of the EU.

However, in adapting the working mechanism of the EU institutions to the challenges posed by BPUfM e.g. finding pillar-cross-cutting solutions, it is in particular the EU Commission which can strengthen its influence by providing analysis, preparing options, and giving guidance for actions over the board. The Commission could further strengthen its grip on the process and is therefore advertising a "deep and comprehensive free trade agreement". In the ensuing negotiations the Commission would be the leader because of its competence in pillar one.

Successful projects whose results are discernible for citizens could contribute to "responding to our citizens' concerns for prosperity, security and stability, not by imposing reforms, but by supporting and encouraging reformers". This is a reference to the 'normative power' of the EU but also a means to overcome the capability-expectation gap in executing manageable projects of mutual interest in a sustainable manner. However, the long list of projects identified by the Foreign Ministers in November 2008 lacks focus and could lead to weakening the process when projects are proposed and adopted to please the proponent and not necessarily to advance the common cause.

At last, analyzed against the background of interregionalism, BPUfM attempts to combine the multilateral approach of the Barcelona Process with the more individualistic bilateral approach of the ENP in putting the emphasis on projects of regional importance, to foster cooperation, and in setting up more common structures, thereby giving more prominence to 
the multilateral approach. However, as Mario Telo observes, "squaring the bilateral and the multilateral dynamics at play within the Barcelona Process $\cdots$ has proven a particularly hard challenge. Energy and migratory concerns look as unresolved issues in the EU relations to its Southern and Easter rims. Also both areas have tested the lacking Union's coherence between the policies originating from its $1^{\text {st }}$ pillar on the one hand, and those from the $2^{\text {nd }}$ and $3^{\text {rd }}$ on the other hand, to the brink." The abolition of the pillar system as enshrined in the aborted Constitutional Treaty and the (pending) Treaty of Lisbon would help overcoming this systemic problem.

Daniele Marchesi regards the Mediterranean as "non-region" because of the political and economic asymmetries, and the failure of the Barcelona Process to create a common identity or foster south-south cooperation. $\mathrm{He}$ nevertheless admits that awareness of the so-called "non-region" has been rising in Europe. The institutional asymmetry shall be corrected through the setting up of common institutions, although the European Commission will be without competition in the Mediterranean context for years to come. The asymmetries hindering progress in EUROMED, "economic underdevelopment of all Mediterranean countries, except Israel, and the general domestic situation of the Arab States, all governed by more or less authoritarian regimes", the wider Middle East problem (including Lebanon) and Western Sahara problem are important obstacles in region building. Open regionalism could provide a framework for further development of communalities among Mediterranean countries, spurred by the need to deal with an institutionalized partner which could become a uniting factor. Unlike the EU itself or ASEM (see below) the geographical ambit and thereby the participatory element of the Mediterranean is clear.

In focusing on the Mediterranean BPUM also redresses to a certain extent the balance of attention and interest extended to the Middle-East and the Mediterranean. The 2004 European Strategic Partnership for the 
The 'Union for the Mediterranean', the European Neighbourhood

Policy and the Barcelona Process: Old wine in new bottles?

(Reiterer)

Middle East linked the Euro-Mediterranean countries simply to the rest of the "countries East of Jordan". According to Marchesi, this attempt at reaching out to the Mediterranean reflects the Union's desire "to promote itself as a power" by building a "bridge to the American policy towards the area, including countries of the Gulf Cooperation Council, Iraq and Iran without properly including these in the EMP” By asserting Europe as a "civilian-normative power" in the Mediterranean, the EU wants to realize its concept of " a ring of friend", as laid out in the 2003 Security Strategy.

\section{Lessons to be learnt from the Asia - Europe relationship?}

However, as the Mediterranean still has a long way to go and is at best a 'region under construction', some insight gained from the analysis of interregionalism could be useful to understand the process. Therefore, a short comparison with the Asia Europe Meeting (ASEM) will follow in an attempt to establish some common as well as diverging features between these two forms of cooperation.

When ASEM was envisaged in 1995 - incidentally in the same year of the Barcelona Declaration - to close the perception gap between Asia and Europe, the idea to fill the missing link in the triangle EU-US-Asia was among the driving forces. Moving away from (post-) colonial attitudes, the need to treat Asian partners as equals was recognized after the acrimonious debate about Asian values. Therefore a partnership of equals was the goal which could not be limited to just economic issues (like APEC) but had to be comprehensive. Thus, ASEM was built on three pillars politics, economics, culture-people to people. Although in theory on equal footing, economics turned out to be the most important pillar, not least because the other two were judged by the Asian partners to be rather sensitive (human rights, civil society groups in opposition to the governments $\cdots$ ). As the Europe-Asia dimension was neglected for long, a dialogue 
process to get to know each other better, an informal approach without a legal or institutional structure, was judged to be the best approach. These ideas also inspired the beginning of the Barcelona Process and continue to influence the BPUM process.

The Mediterranean partners share the aversion of Asian partners to being lectured by Europeans. This is particularly true when the lecturers are former colonial powers talking about Western values, human rights and good governance. In the Mediterranean context the value argument is stronger developed as practically all Mediterranean partners are Islamic and common religion and traditions form a sort of unifying band. However, many of the countries are governed by secular regimes attempting to suppress (radical) Muslim movements. This constitutes a homemade high potential not only for domestic but also regional conflicts. Because of the diversity of the Asian partners this band does not exist in Asia although Indonesia is the largest Muslim country in the world and Malaysia has a strong Muslim tradition. Thus, the European, Western values vs. Asian values vs. values strongly influenced by Islam, play a role.

This leads in the Asian and Mediterranean context to a difficulty for the EU in particular to work closely and implement a value based foreign policy with partners having problems with human rights, rule of law and democracy.

Lacking a sound common basis broadens the problem of having partners in the same structure who are parties to a conflict. In the context of the BPUM and the Barcelona Process this is primarily the Arab-Israeli conflict, but also the tensions between Syria and Lebanon and the West Sahara conflict, to name just a few. In the ASEM context this applies to the Indo-Pakistani conflict and the many territorial disputes among Asian ASEM partners, in particular China, South Korea and Japan, not to mention the problem of Taiwan. While Libya managed to change its image of a pariah state, Burma/Myanmar shows no sign of change, 
despite hopes when first joining ASEAN (1997) and then ASEM (2002).

In both cases it is difficult to bring countries to work together when the political systems differ widely-democracies and dictatorships or autocratic regimes, market economies and communist state interventionist schemes.

The visibility and credibility of dialogue processes vis-à-vis the public is rather limited. The many meetings have to be justified (at least in democratic regimes) and it is hard to explain that talking to get to know each other might be useful in the long run. Therefore projects, deliverables are sought for. While ASEM had to define and create them overtime, BPUM learnt from this experience and starts from the outset as a project driven process, having chosen areas of cooperation which should allow demonstrating their utility to the general public if they succeed.

A free trade agreement 2010, developed in the Barcelona Process, remains on the BPUM agenda. In ASEM a FTA was suggested by the ASEM Vision Group (1999) from the outset, but not accepted as part of the work programme or the ASEM rules book, AECF 2000.

In contrast to ASEM which was proud to being an informal dialogue, BPUM starts with a technical secretariat and clearer structure aiming at correcting the institutional asymmetry. The sheer number of partners involved the need to manage projects and prepare meetings lead to this decision. This also introduces an element of equal opportunities as the EU side in the partnership can profit from the institutional structure of the Union and the European Commission as a policy preparing institution. This imbalance lead to frustration of the Asian ASEM partners; as a first step the ASEAN Secretariat was admitted as a partner in its own right and an ASEAN Charter developed. An ASEM Secretariat remains an issue of discussion; a Virtual Secretariat attempts bridging the gap for the time being.

In order to better involve grass root organizations, artists, writers, academia, young parliamentarians, and civil society in general $\cdots$ even 
ASEM recognized from the outset that an institution was necessary to provide these diverse and dispersed groups with a platform. Therefore the Asia Europe Foundation (ASEF) was set up already in 1997 in Singapore. The corresponding Anna Lindh Foundation is clearly inspired and modeled after ASEF.

Both, ASEM and BPUM contribute to increased governance as they constitute regimes, although of a different quality. While the Mediterranean is traditionally part of Europe's sphere of influence and interest, Asia had to be brought closer to Europe. However, the perception has changed over the last decades: Asia has become the focus of interest not only of Europe but of the world wide political system, although in different forms : first the Asia of Japan and the 'Tigers' in the flying geese pattern and then the Asia of the confident China and India both resurrecting after the Asian Financial Crisis. In comparison, the Mediterranean partners lag behind politically and economically and therefore have to compete for attention with Eastern Europe.

The Barcelona Process, set in motion in 1995, gained additional standing through the ENP and attempted to bring the Mediterranean closer to the EU. This is of relevance as the EU's soft power is the bigger the closer a partner is geographically and the more interested this partner is in having a close relationship with the EU. Hence, if a partner is interested in joining the EU, soft power is strongest. However, the growing awareness of the importance of energy security strengthens the power of those Mediterranean countries which are energy suppliers.

Conversely, the soft power of the Union is smaller in Asia, since it is limited to the economic and financial sphere, but lacking the instrument of conditionality to influence policies of partners far away or relatively strong. Charalambos Tsardanidis draws from this analysis the conclusion that "with weaker states the EU dictates much more of the conditions for interregional cooperation". He also regards the development form EMP to ENP since 2004 as a move from "asymmetrical inter-regionalism towards 
dependencia regionalism". Therefore for Tsardanidis, the ENP is not a form of inter-regionalism but rather "a process of 'regionalism through interregionalism' which will lead to the Urals and the Caucasus and from the Barents Sea to Sahara desert based on homocentric circles of integration." In Marchesi's analysis, the "largely Euro-centric approach of the Barcelona Process and its 'hub-and-spokes' logic, which reduced enthusiasm on the southern shores from the outset, is the 'original sin' of the Euro-Mediterranean Partnership." In stressing co-ownership, in establishing for the first time a co-presidency, a joint Secretariat and a Joint Permanent Committee, the BPUM attempts to correct these shortcomings.

Interregional regimes based on mutual interest with agreed behaviour or rules, that make use of the tool of dialogue, exchanges and projects to create not only networks but concrete ties while respecting differences in culture and values, contribute to generating levels of interregional governance within the multilayered international governance system. The leverage of the EU's soft and normative power certainly contributes to these processes. BPUfM refocuses the ENP which in Mahncke's perspective is "based on a reasoned foreign policy concept $\cdots$ [involving] all aspects of issues to be dealt with:foreign policy, domestic policies (from democratization to culture), political as well as economic matters". Like in the ASEM process, the BPUfM, built on the ENP, further develops the crosspillar approach, which is essential for rendering the EU foreign policy more effective despite the blockage of the Lisbon Treaty.

The BPUfM also shares with ASEM the fact that the Europeanization of partner countries cannot be the policy goal-unlike ENP vis-à-vis Eastern European countries. Respect for cultural and religious diversity limits substantially "norm export" by the EU to the countries at the Southern shore of the Mediterranean as part of the EU's "soft diplomacy". The EU faces a completely different situation when it comes to its Eastern European neighbours, since some of them are willing to adapt to the system of the Union and to adopt its values in order to gain or 
『日本 $\mathrm{EU}$ 学会年報』第 29 号, 平成 21 年 4 月

maintain an accession perspective.

In reference to the title of the paper, 'Old wine in new bottles?' I would invert the sequence and conclude:the BPUfM offers partly new wine while making use of old bottles with a new label. Whether a bit of new wine mixed with old wine makes a good cuvée, may need a good sommelier to establish. And, last but not least in order to stay politically correct, for our Islamic partners the metaphor should rather be about old tea in a new tea kettle.

* Adjunct Professor for International Politics University of Innsbruck.

This paper is based on a presentation made at the EU GAKKAI annual meeting at Shizuoka, November 23, 2008. (The author expresses his own views which should not be attributed in any way to the European Commission.) Contact:michaelreiterer@hotmail. com

1) On this issue: Michael Reiterer (2008). "EU Foreign Policy:From Cooperation to Diplomacy”. EU Studies in Japan, no. 28; pp. 27-44.

2) http ://ec. europa.eu/external_relations/euromed/index_en. htm

3 ) http ://ec. europa. eu/external_relations/enp/index_en. htm

4 ) Benita Ferrero-Waldner (2006) “The European Neighbourhood Policy: The EU's Newest Foreign Policy Instrument”. European Foreign Affairs Review, vol 11; p. 140.

5 ) Dieter Mahncke (2008). "The Logic of EU Neighbourhood Policy" in Mahncke/Gstoehl (eds.) Europe's Near Abroad (2008), College of Europe Studies no. 4. p. 23.

6) COM (2003) 104 final, March 11, 2003. http://ec. europa. eu/world/enp/pdf/com03_104_ en. pdf

7) COM (2004) 373 final, May 12, 2004. http://ec. europa. eu/world/enp/pdf/strategy/ strategy_paper_en.pdf

8) COM (2006) 726 final, December 4, 2006. http://ec. europa. eu/world/enp/pdf/com06_ 726_en. pdf

9) Mahncke (2008); p. 33.

10) Neighbourhood Policy Paper. op. cit.

11) A Secure Europe in a Better World. European Security Strategy (2003); December 12; (emphasis added). http://www. consilium. europa. eu/uedocs/cmsUpload/78367. pdf

12) S113/08, March 14, 2008; http://www. consilium. europa. eu/ueDocs/cms_Data/docs/ pressdata/EN/reports/99387. pdf

13) http://ec. europa. eu/external_relations/north_dim/index. htm; see also:Adele Airoldi 
The 'Union for the Mediterranean', the European Neighbourhood

Policy and the Barcelona Process : Old wine in new bottles?

(Reiterer)

(2008). The European Union and the Arctic. Policies and actions. Nordic Council of Ministers, Copenhagen.

14) http://www. consilium. europa. eu/ueDocs/cms_Data/docs/pressdata/en/er/101847.pdf

15) Work Programme of the Czech Presidency, Europe without Barriers (2009) http:// www. eu2009. cz/en/czech-presidency/programme-and-priorities/programme-and-priorities -479

16) Barcelona Process: Union for the Mediterranean ministerial conference. Marseille 3-4 November 2008, Final declaration http://www. consilium. europa. eu/ueDocs/cms_Data/ docs/pressdata/en/misc/103733. pdf

17) http ://ec. europa. eu/external_relations/euromed/index_en. htm

18) http ://europa. eu/scadplus/leg/en/lvb/r15001. htm

19) EU Mediterranean Trade, Press release, July 2, 2008. http://trade. ec. europa. eu/doclib/ docs/2008/july/tradoc_139445. pdf See also Euro-Mediterranean Statistics 2007 at http:// trade. ec. europa. eu/doclib/docs/2008/may/tradoc_138834.pdf

20) Michael Emerson (2008). "Making sense of Sarkozy's Union for the Mediterranean". CEPS Policy Briefs no. 155 ; p. 4.

21) These are Albania, Algeria, Egypt, Israel, Jordan, Lebanon, Libya, Mauritania, Morocco, Occupied Palestinian Territory, Syria, Tunisia, Turkey.

22) http://www. bilaterals. org/article. php3?id_article=2513. The Agreement entered into force in 2006 only.

23) http ://ec. europa. eu/taxation_customs/customs/customs_duties/rules_origin/preferential/article_783_en. htm

24) Daniel Mueller-Jentsch (2005). Deeper Integration and Trade in Services in the EuroMediterranean Region. The World Bank (2005). http://trade. ec. europa. eu/doclib/docs/ 2005/july/tradoc_124235.pdf

25） http ://www. u-m-p.org/site/index. php/ump/s_informer/discours/nicolas_sarkozy_a_ toulon (my translations).

26) Romano Prodi (2002). "A Wider Europe - A Proximity Policy as the Key to stability" Speech, Brussels http://europa. eu/rapid/pressReleasesAction. do?reference=SPEECH/02/ $619 \&$ format $=$ HTML\&aged $=0$ \&language $=$ EN\& guiLanguage $=$ en

27) Frankfurter Allgemeine Zeitung (2008). September 1. http : //www. faz. net/s/Rub97F2F5D596354F4BBE619038133D791F/Doc E49C87161BC1 842A9BF8133DA69FFC151 ATpl Ecommon Scontent. html

28) The June 2008 European Council had already endorsed the Black Sea Synergy (para. 69) http://www. eu2008. si/en/News_and_Documents /Council_Conclusions / June / 0619 _ EC-CON. pdf

29) http ://ec. europa. eu/external_relations/eastern/index_en. htm;

30) Eastern Partnership. COM (2008) 823/4, http://ec. europa. eu/external_relations/east- 
『日本 $\mathrm{EU}$ 学会年報』第29号, 平成21年 4 月

ern/docs/com08_823_en. pdf (see also note 13 above).

31) http ://ec. europa. eu/external_relations/russia/common_spaces/index_en. htm

32) http ://eur-lex. europa. eu/LexUriServ/LexUriServ. do?uri=CELEX:21997A1128(01):EN: NOT

33) http:// www. euractiv. com / en / enlargement / hello-neighbour-new-eu-policy-morocco-azerbaijan/article-174054 Rene Wadlow (2008) "The Mediterranean Black Sea Union: The Ship sets sail" (July 16) http://towardfreedom.com/home/content/view/1355/

34) http://www. bsec-organization. org/Pages/homepage. aspx

35) "Regimes can be defined as sets of implicit or explicit principles, norms, rules and decision-making procedures around which actor's expectations converge in a given area of international relations." Stephen Krasner (ed.) (1983) International Regimes (Ithaca: Cornell University Press)

36) COM (2007) 160final. http://ec. europa. eu/world/enp/pdf/com07_160_en. pdf; special website : http ://ec. europa. eu/external_relations/blacksea/index_en. htm

37) COM (2008) 391final. Report on the first year of implementation of the Black Sea Synergy http://ec. europa. eu/external_relations/blacksea/doc/com08_391_en.pdf

38) COM (2008) 319 (Final), May 20, 2008; http: // ec. europa. eu/external_relations / euromed/docs/com08_319_en. pdf

39) The Foundation named in honour of the assassinated Swedish Foreign Minister Anna Lindh was set up in 2005 by the Euro-Med Partnership to support organizations and individuals working for the promotion of dialogue and the political objective of shaping the Euro-Mediterranean region as 'an area of co-operation, exchange, mobility, mutual understanding and peace'. http://www. euromedalex. org/Home/En/Home. aspx

40) Union for the Mediterranean: Building on the Barcelona acquis (2008). European Union Institute for Security Studies, Paris, ISS Report No. 1. http://www. iss. europa. eu/uploads /media/ISS_Report01.pdf See also Abdallah Saaf (2008). L'Union pour la Méditerranée et les acquis civils de Barcelone. Issues 26, July; http://www. iss. europa. eu/uploads/media/ newletter26web. pdf

41) http ://europafrica. org/jointstrategy

42) http://www. consilium. europa. eu/ueDocs/cms_Data/docs/pressdata/en/er/101847. pdf

43) http://ec. europa.eu/external_relations/euromed/summit1105/terrorism_en. pdf

44) Declaration of Foreign Ministers (2008); see note 16 above.

45) Ibid.

46) Neue Zürcher Zeitung (2009). "Parallele Reisediplomatie Sarkozys in Nahost". January, 5 ; p. 3.

47) Richard Gillespie (2008). "A 'Union for the Mediterranean'... or for the EU?". Mediterranean Politics, vol. 13, no. 2; p. 278.

48) Strengthening the European Neighbourhood Policy (2006) http://ec. europa. eu/world/ 
The 'Union for the Mediterranean', the European Neighbourhood

Policy and the Barcelona Process : Old wine in new bottles?

(Reiterer)

enp/pdf/com06_726_en.pdf; at p. 3.

49) Benita Ferrero-Waldner (2006); p. 140.

50) Michael Reiterer (2006). "Interregionalism as a New Diplomatic Tool: The EU and East Asia". European Foreign Affairs Review 11; pp. 223-243. (2008) "The Role of ASEM in EU-Asia Relations: Fostering a Multipolar World through Inter-regional Cooperation" Asia Europe Journal (2009, 7; pp. 179-196, also published on line October 31 at www. springerlink. com/content/h7045g71733576g0) and the literature quoted therein on interregionalism and ASEM.

51) Mario Telo (2007). "Strategic Partnership and Regional Integration. Complementary or Contradictory?" Studia Diplomatica, vol. LX, no. 4; p. 34.

52) Article 8 of the consolidated Lisbon Treaty specifically deals with neighbouring countries: "1. The Union shall develop a special relationship with neighbouring countries, aiming to establish an area of prosperity and good neighbourliness, founded on the values of the Union and characterised by close and peaceful relations based on cooperation.

2. For the purposes of paragraph 1, the Union may conclude specific agreements with the countries concerned. These agreements may contain reciprocal rights and obligations as well as the possibility of undertaking activities jointly. Their implementation shall be the subject of periodic consultation."

http : // eur-lex. europa. eu/LexUriServ/LexUriServ. do? uri = OJ:C:2008:115:0013:0045: $\mathrm{EN}: \mathrm{PDF}$

53) Daniele Marchesi (2008). "From EMP to ENP. Saving the Southern Periphery from Marginalisation?” in Mahncke/Gstoehl (2008); pp. 188-189.

54) Ibid.; p. 199.

55) Daniele Marchesi (2008); pp. 205-206.

56) Sebastian Bersick (2007). "Inter-regional Cooperation Beyond ASEM@10:Responding to Rising Extremism and Resurging Nationalism". Panorama, no. 1; p. 66.

57) Charalambos Tsardanidis (2007). "Quo Vadis Euro-Mediterranean Partnership EMP?" paper prepared for the conference "The Euro-Mediterranean Partnership (EMP) : Perspectives from the Mediterranean EU countries" organised by The Institute of International Economic Relations, Athens, The Foundation for Mediterranean Studies, Athens, the Jean Monnet European Centre of Excellence, Department of Sociology University of Crete, University of Crete, Rethymnon, 25-27 October (quote with permission of the author). http: //www. idec. gr/iier/new / EN/Tsardanidis $\% 20-\%$ 20QUO\% 20VADIS-\%20EMP-\%20Rethymnon,\%2025-10-2007. pdf

58) Marchesi (2008); pp. 199-200.

59) Dieter Mahncke (2008); pp. 45-46.

60) Sieglinde Gstoehl (2008). „The EU as a Norm Exporter?“ in Mahncke/Gstoehl (2008); p. 292. 